\title{
Effects of Different Application Approaches with Diniconazole on the Inhibition of Stem Elongation and the Stimulation of Root Development of Cylindrical Paper Pot Seedling
}

\author{
Dong Cheol Jang ${ }^{1 \dagger}$, Chan $\mathrm{Xu}^{2 \dagger}$, Si Hong Kim², Dae Hoon Kim², Jae Kyung Kim², Jae Yun Heo ${ }^{3}$, \\ Ngoc Thang $\mathrm{Vu}^{4}$, Ki Young $\mathrm{Choi}^{5}$, and II Seop Kim ${ }^{6 *}$ \\ ${ }^{1}$ Post-doc, Department of Horticulture, Kangwon National University, Chuncheon 24341, Korea \\ ${ }^{2}$ Graduate Student, Department of Horticulture, Kangwon National University, Chuncheon 24341, Korea \\ ${ }^{3}$ Professor, Department of Plant Science, Gangneung-Wonju National University, Gangneung 25457, Korea \\ ${ }^{4}$ Lecturer, Faculty of Agronomy, Vietnam National University of Agriculture, Hanoi, Vietnam \\ ${ }^{5}$ Professor, Department of Controlled Agriculture, Kangwon National University, Chuncheon 24341, Korea \\ ${ }^{6}$ Professor, Department of Horticulture, Kangwon National University, Chuncheon 24341, Korea
}

\begin{abstract}
This study was conducted to compare the effects of foliar spray and sub-irrigation of the triazole fungicide diniconazole on the regulation of stem elongation and to investigate the stimulation of root system development during the seedling stage. Comparing the two application approaches, there were significant differences in the leaf area, leaf area ratio (LAR), plant height, compactness, fresh shoot and root production, relative growth rate (RGR), and root to shoot ratio $(\mathrm{R} / \mathrm{S})$. At the same application concentration, the sub-irrigation showed a better retarding effect on growth than the foliar spray, because the PGR activity of diniconazole in root absorption was higher than that in shoot absorption. For reaching a target of $20 \%$ to $30 \%$ inhibition rate of stem length, foliar application concentration of diniconazole exceeded 10 , however, only approximately 1 was required in the sub-irrigation application. The root system of tomato seedlings responded strongly to diniconazole application. Total root length, root volume, root average diameter, and the number of root tips increased when diniconazole was sub-irrigation application at 1 . A reduction in fine roots (diameter range of 0 to $0.3 \mathrm{~mm}$ ) and an increase in the roots with a diameter range of 0.3 to $0.6 \mathrm{~mm}$ was observed, and this may contribute to the increase in average diameter. The increase in root average diameter may be positive because root penetration increases with root diameter. Our results suggested that sub-irrigation maximized the PGR activity of diniconazole to enhance the retarding effect. And it also possible to enhance the tomato seedling root system by diniconazole stimulating with a lower concentration.
\end{abstract}

Additional key words : growth control, over-growth, rhizosphere, triazole compounds, tomato seedling

\section{Introduction}

Plug seedling production system meets the rapidly increasing demand for high-quality seedlings which is not only performed in the stocky size of shoots but also in a highly developed root system. Overgrowth in the stem is one of the major problems in this system caused by the high seedling density and excessively elongated stem seriously declines seedling quality (Zhang et al., 2003).

The application of plant growth regulators (PGR) is a reliable and precise method to overcome this issue (Choi et al., 2011). Some triazole based fungicides both have PGR

\footnotetext{
$\dagger$ These authors contributed equally to this work

*Corresponding author: kimilsop@kangwon.ac.kr

Received August 11, 2020; Revised August 31, 2020;

Accepted September 02, 2020
}

property have been applied in various plants, they protect plants from varieties of environmental stresses (Fletcher et al., 2000; Kishorekumar, 2006). Existing studies have recognized the PGR property of triazole compounds that it affects the isoprene pathway and shifts in the balance of certain important hormones such as ethylene, gibberellin, abscisic acid (ABA), and cytokinin (Fletcher et al., 2000; Jaleel et al., 2008), and thus regulating the growth of plants. In seedling production, the triazole compounds have been stated to be effective in controlling plant height growth (Jung et al., 2020; Kim and Suzuki, 1989; Zhang et al., 2003). Also, triazole compounds have been shown to influence root growth, however, the effect may be either inhibitory or stimulatory, depending on the species and the concentration (Fletcher et al., 2000). Althought Kim and Suzuki (1989) reported that triazole without affecting the 
Dong Cheol Jang, Chan Xu, Si Hong Kim, Dae Hoon Kim, Jea Kyung Kim, Jea Yun Heo, Ngoc Thang Vu, Ki YoungChoi, and Il Seop Kim

roots only reduced the growth of stems and leaves, significant changes in the development of the root system caused by triazole compounds have been observed in many species (Bausher and Yelenosky, 1987; Kvien et al., 1987). Those growth indexes have determined the positive effect on root growth, however, it still failed to describe the characteristic of the root system affected by triazole compounds.

Few writers have been able to draw on any systematic research into root system development affected by triazole compounds (Cho and Chiang, 1997). Besides, there is still uncertainty whether applying triazole compounds to different organs will have different responses in tomato seedling. The objectives of this study were to compare the effects of foliar spray and sub-irrigation of the triazole fungicide diniconazole on the regulation of stem elongation and to investigate the stimulation of root system development.

\section{Materials and Methods}

\section{Plant material and growth conditions}

Grafted tomato seedlings from Hoban Seedling Company (Chuncheon, Korea) were used. Seeds of Scion cultivar 'Ariadni' were sown on 4 April 2019 and tomato rootstock 'Pentagon' on 6 April 2019. They were sown in 128-hole plug trays (Bumnong Co., Ltd., Jeongeup, Korea) filled with a commercial substrate (BM2, Berger Group Ltd., Quebec, Canada). Then 30 days after sowing, scion cultivar was grafted onto the tomato rootstock using the splice grafting method. The grafted seedling was grown in a cylindrical paper pot placed in the 32-hole plug trays. When the surviving grafted seedlings had grown strong enough, the seedlings were transported from Hoban's seedling nursery to the experimental greenhouse on the farm of Kangwon National University (Chuncheon, Korea) for diniconazole treatment. During the experiment, commercial fertilizer (Wonder Grow Fertilizers, Chobi Co., Ltd., Seoul, Korea) was applied to the seedlings twice a week, the same management as at the Hoban seedling nursery. The experiments were carried out from April to June 2019 in the experimental greenhouse on the farm of Kangwon National University.

\section{Foliage spray and sub-irrigation treatments}

Diniconazole was provided by the Dongbang Agro Company (Seoul, Korea). Its product name is 'Binnari', and it has $5 \%$ net content. Control plants were maintained with no diniconazole application, using the same cultivation method as in the Hoban seedling nursery. The diniconazole solutions were prepared by dissolving Binnari in tap water to make 1,10 , and $30 \mathrm{mg} \cdot \mathrm{L}^{-1}$ solutions. In the foliage spray treatment, seedlings were sprayed until all the leaves were thoroughly wetted. In the sub-irrigation treatment, the diniconazole was applied to the substrate and completely saturated the substrate. Both spray and sub-irrigation were treated once on 26 May 2019, and all the seedlings were grown in the greenhouse.

\section{Data collection and analysis}

Growth measurements and sampling were performed on 26 May 2019 and every 5 days after that. Since the growth suppressing effect from triazole compounds is temporary and ephemeral (Lee and Rho, 2000) and diniconazole did not affect the flowering and fruit-bearing development of tomatoes, a total of 5 sampling sessions were conducted. The weight of the seedlings was then measured using an electronic balance. The plant height was measured from the main stem base to the top of the young plants using a ruler, and the stem diameter was measured at the internode above cotyledons using vernier calipers. The total leaf areas were determined using a leaf area meter (LI-3100C; LI-COR, Lincoln, NE, USA). Plant tissue dry weights were obtained after drying at $80^{\circ} \mathrm{C}$ for at least $72 \mathrm{~h}$ in the oven (Mov-212F, Sanyo Electric Co., Ltd., Osaka, Japan). The relative chlorophyll contents of leaves were determined using a SPAD analyzer (SPAD-502 Plus, Konica Minolta Sensing Inc., Osaka, Japan).

Growth analysis parameters, including relative growth rates (RGR), and leaf area ratio were calculated using the following equations (Zhang et al., 2017):

$$
\begin{aligned}
& \mathrm{RGR}=\frac{1}{W} \times \frac{\Delta W}{\Delta t}=\frac{\operatorname{In}\left(W_{2}\right)-\operatorname{In}\left(W_{1}\right)}{t_{2}-t_{1}} \\
& W_{1} \text { and } W_{2}: \text { initial and final total dry weight of whol plant, } \\
& t_{2}-t_{1}: \text { growing period (days) }
\end{aligned}
$$


Effects of Different Application Approaches with Diniconazole on the Inhibition of Stem Elongation and the Stimulation of Root...

$$
L A R=\frac{L}{W}=\frac{\frac{L_{1}}{W_{2}}+\frac{L_{2}}{W_{2}}}{2}
$$

The substrate was gently removed by flowing water. After the root systems cleaning the high complexity first-order lateral roots were separated from the axile root. The whole root system of each sample was stored in a plastic tube. Roots were scanned with a flatbed scanner (Epson Perfection V800 Photo color scanner, USA) at a resolution of 400 d.p.i. The root images were analyzed using a WinRHIZO Pro 2009b (Re' gent Instruments Inc., Quebec City, Canada) imageanalysis system. We performed the analysis of variance (ANOVA) to assess growth parameters compared with control, and the significant differences among all treatments were compared using Ducan's multiple range test at 5\%. We also performed the general linear model (GLM) for comparing the effect of spray and sub-irrigation. Betweensubject effects evaluated variances of treatment methods, diniconazole concentration, and interaction effects. The SPASS Statistics software V24 was used for this purpose.

\section{Results}

Results of between-subject effects showed that the dwarf effect of tomato seedlings significantly differed between application methods. Both foliar spray and sub-irrigation diniconazole decreased stem elongation at 10 and $30 \mathrm{mg} \cdot \mathrm{L}^{-1}$ solution concentration but the reduction varied greatly

Table 1. Comparison of foliar spray and sub-irrigation diniconazole on leaf growth character, plant height, and compactness of tomato seedlings.

\begin{tabular}{|c|c|c|c|c|c|c|c|}
\hline $\begin{array}{l}\text { Treatment } \\
\text { methods }\end{array}$ & $\begin{array}{c}\text { Concentration } \\
0 \\
\end{array}$ & No. of leaves & $\begin{array}{l}\text { Leaf chlorophyll } \\
\text { content (SPAD) }\end{array}$ & $\begin{array}{c}\text { Leaf area } \\
\left(\mathrm{cm}^{2}\right)\end{array}$ & $\begin{array}{l}\text { Leaf area ratio } \\
\left(\mathrm{cm}^{2} \cdot \mathrm{g}^{-1}\right)\end{array}$ & $\begin{array}{c}\text { Plant height } \\
(\mathrm{mm})\end{array}$ & $\begin{array}{c}\text { Compactness } \\
\left(\mathrm{mg} \cdot \mathrm{cm}^{-1}\right)\end{array}$ \\
\hline Control & 0 & $10.3 \mathrm{a}^{\mathrm{x}}$ & $47.6 \mathrm{c}$ & $348.3 \mathrm{a}$ & $106.4 \mathrm{ab}$ & $435.8 \mathrm{a}$ & $74.1 \mathrm{c}$ \\
\hline \multirow{3}{*}{ Foliar spray } & 1 & $10.5 \mathrm{a}$ & $49.6 \mathrm{bc}$ & $338.2 \mathrm{a}$ & $99.5 \mathrm{abc}$ & $435.3 \mathrm{a}$ & $78.6 \mathrm{c}$ \\
\hline & 10 & $10.3 \mathrm{a}$ & $53.2 \mathrm{ab}$ & $270.6 \mathrm{~b}$ & $114.6 \mathrm{a}$ & $385.5 \mathrm{ab}$ & 84.4 bc \\
\hline & 30 & $9.8 \mathrm{a}$ & $55.1 \mathrm{a}$ & $267.3 \mathrm{~b}$ & $82.9 \mathrm{c}$ & $316.0 \mathrm{c}$ & $77.9 \mathrm{c}$ \\
\hline \multirow{3}{*}{ Sub-irrigation } & 1 & $9.8 \mathrm{a}$ & $51.5 \mathrm{abc}$ & $277.6 \mathrm{~b}$ & $88.9 \mathrm{bc}$ & $363.3 \mathrm{~b}$ & $86.5 \mathrm{bc}$ \\
\hline & 10 & $9.3 \mathrm{a}$ & $52.8 \mathrm{ab}$ & $270.2 \mathrm{~b}$ & $103.3 \mathrm{abc}$ & $271.5 \mathrm{~cd}$ & $96.8 \mathrm{ab}$ \\
\hline & 30 & $9.5 \mathrm{a}$ & $53.4 \mathrm{ab}$ & $236.1 \mathrm{~b}$ & $100.1 \mathrm{abc}$ & $230.5 \mathrm{~d}$ & $100.4 \mathrm{a}$ \\
\hline \multirow{3}{*}{ Significance $^{\mathrm{y}}$} & Treatment (T) & NS & NS & $* * *$ & $*$ & $* * *$ & $* * *$ \\
\hline & Concentration (C) & NS & $* *$ & $* * *$ & $*$ & $* * *$ & NS \\
\hline & $\mathrm{T} \times \mathrm{C}$ & NS & NS & NS & NS & $*$ & NS \\
\hline
\end{tabular}

${ }^{\mathrm{x}}$ Mean separation within columns by Duncan's multiple range test at $5 \%$ level.

${ }^{\mathrm{y}} \mathrm{NS}, *, * *$, and $* * *$ indicate not significant or significant differences of $\mathrm{P} 0.05,0.01$, and 0.001 , respectively.

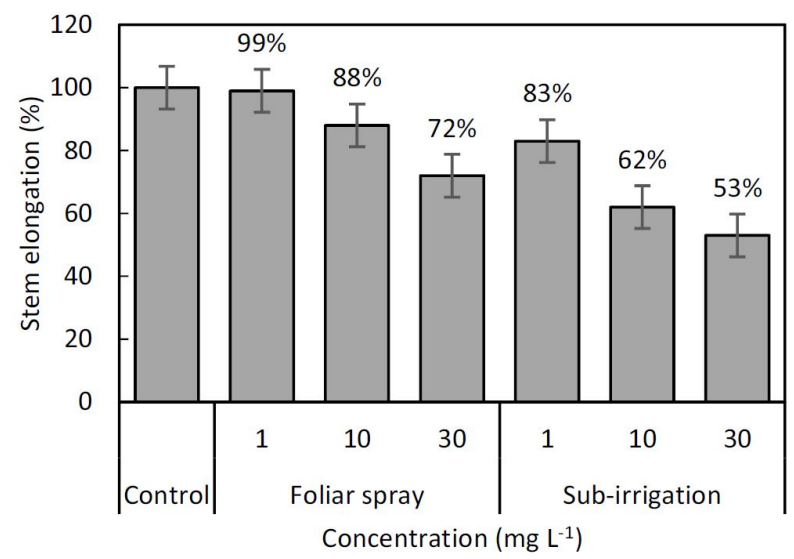

Fig. 1. Dwarf effects of foliar spray and sub-irrigation on stem elongation growth. 
Dong Cheol Jang, Chan Xu, Si Hong Kim, Dae Hoon Kim, Jea Kyung Kim, Jea Yun Heo, Ngoc Thang Vu, Ki YoungChoi, and Il Seop Kim

(Table 1, Fig. 1). As compared with the control, diniconazole at $30 \mathrm{mg} \cdot \mathrm{L}^{-1}$ decreased plant height by $27 \%$ and $47 \%$, at $20 \mathrm{mg} \cdot \mathrm{L}^{-1}$ decreased by $12 \%$ and $38 \%$ for spray and subirrigation, respectively. Sub-irrigation diniconazole at $1 \mathrm{mg}$. $\mathrm{L}^{-1}$ decreased plant height by $17 \%$, however, no decrease was observed in spray treated seedlings (Table 1, Fig. 1). Both the two application methods increased compactness, diniconazole at 1,10 and $30 \mathrm{mg} \cdot \mathrm{L}^{-1}$ increased the compactness by $6 \%, 13 \%$, and $5 \%$ in spray treatments, and increased by $16 \%, 30 \%$, and $35 \%$ in sub-irrigation treatments. But there was also a significant difference in compactness between the two application methods (Table 1).

The growth responses of the above-ground showed significant differences between spay and sub-irrigation treatments. Substrate applied diniconazole showed lower leaf area and fresh shoot weight compared with spray (Table
1 and 2). There were also significant differences in relative growth rate (RGR) and root to shoot ratio of fresh weight $(\mathrm{R} / \mathrm{S})$ between the two application methods (Table 2). During seedling raising after diniconazole treatment, the relative growth rate of the shoot of all the treated seedlings was lower than control 5 days after the diniconazole application, however, the relative growth rate of the root in sub-irrigation treatments was larger than control in sub-irrigation treatments (Fig. 2 and 3). The R/S in substrate sub-irrigation treatment tended to be larger than control and remained at a large value during this period, however, in foliar spray treatment, it failed to remain this trend (Fig. 4).

The root system of tomato seedlings responded strongly to diniconazole application. Mean $(\bar{x} \pm S E)$ of total root length per plant varied from $9.87 \pm 0.89 \mathrm{~m}$ to $14.4 \pm 0.63 \mathrm{~m}$ after 15 days growing period. There were increases in total root

Table 2. Comparison of foliar spray and sub-irrigation diniconazole on shoot and root production, relative growth rate (RGR), and root to shoot ratio $(\mathrm{R} / \mathrm{S})$ of tomato seedlings.

\begin{tabular}{|c|c|c|c|c|c|c|c|c|c|}
\hline \multirow{2}{*}{$\begin{array}{l}\text { Treatment } \\
\text { methods }\end{array}$} & \multirow{2}{*}{$\begin{array}{c}\text { Concentration } \\
(0)\end{array}$} & \multicolumn{3}{|c|}{ Fresh weight (g) } & \multicolumn{3}{|c|}{ Dry weight (g) } & \multirow{2}{*}{$\begin{array}{c}\text { RGR } \\
\left(g^{\prime} \cdot g^{-1} \cdot \text { day }^{-1}\right)\end{array}$} & \multirow{2}{*}{$\mathrm{R} / \mathrm{S}$ ratio } \\
\hline & & Shoot & Root & Tatol & Shoot & Root & Total & & \\
\hline Control & 0 & $18.2 \mathrm{a}^{\mathrm{x}}$ & $3.99 \mathrm{ab}$ & $22.2 \mathrm{ab}$ & $2.93 \mathrm{a}$ & $0.35 \mathrm{ab}$ & $3.29 \mathrm{a}$ & $0.53 \mathrm{a}$ & $0.22 \mathrm{c}$ \\
\hline \multirow{3}{*}{ Foliar spray } & 1 & $18.9 \mathrm{a}$ & $4.00 \mathrm{ab}$ & $22.9 \mathrm{a}$ & $3.05 \mathrm{a}$ & $0.37 \mathrm{a}$ & $3.42 \mathrm{a}$ & $0.54 \mathrm{a}$ & $0.21 \mathrm{c}$ \\
\hline & 10 & $16.9 \mathrm{ab}$ & $3.83 \mathrm{ab}$ & $20.8 \mathrm{abc}$ & $2.83 \mathrm{a}$ & $0.39 \mathrm{a}$ & $3.22 \mathrm{ab}$ & $0.53 \mathrm{ab}$ & $0.23 \mathrm{c}$ \\
\hline & 30 & $14.3 \mathrm{c}$ & $3.26 \mathrm{c}$ & $17.6 \mathrm{~cd}$ & $2.12 \mathrm{c}$ & $0.28 \mathrm{~b}$ & $2.40 \mathrm{c}$ & $0.47 \mathrm{c}$ & $0.23 \mathrm{c}$ \\
\hline \multirow{3}{*}{ Sub-irrigation } & 1 & $17.3 \mathrm{ab}$ & $4.33 \mathrm{ab}$ & $21.6 \mathrm{ab}$ & $2.76 \mathrm{ab}$ & $0.38 \mathrm{a}$ & $3.14 \mathrm{ab}$ & $0.52 \mathrm{ab}$ & $0.25 \mathrm{bc}$ \\
\hline & 10 & $14.8 \mathrm{c}$ & $4.38 \mathrm{a}$ & $19.1 \mathrm{bcd}$ & $2.27 \mathrm{bc}$ & $0.36 a b$ & $2.63 \mathrm{bc}$ & $0.49 \mathrm{bc}$ & $0.30 a b$ \\
\hline & 30 & $12.8 \mathrm{~d}$ & $4.22 \mathrm{ab}$ & $17.0 \mathrm{~d}$ & $2.01 \mathrm{c}$ & $0.35 \mathrm{ab}$ & $2.36 \mathrm{c}$ & $0.46 \mathrm{c}$ & $0.33 \mathrm{a}$ \\
\hline \multirow{3}{*}{ Significance $^{\mathrm{y}}$} & Treatment $(\mathrm{T})$ & $* * *$ & $*$ & $*$ & $* *$ & NS & $*$ & $*$ & $* * *$ \\
\hline & Concentration (C) & $* * *$ & NS & $* * *$ & $* * *$ & NS & $* * *$ & $* * *$ & * \\
\hline & $\mathrm{T} \times \mathrm{C}$ & NS & NS & NS & NS & NS & NS & NS & NS \\
\hline
\end{tabular}

${ }^{\mathrm{x}}$ Mean separation within columns by Duncan's multiple range test at $5 \%$ level.

${ }^{\mathrm{y} S}, * * *$, and $* * *$ indicate not significant or significant differences of $\mathrm{P} 0.05,0.01$, and 0.001 , respectively.
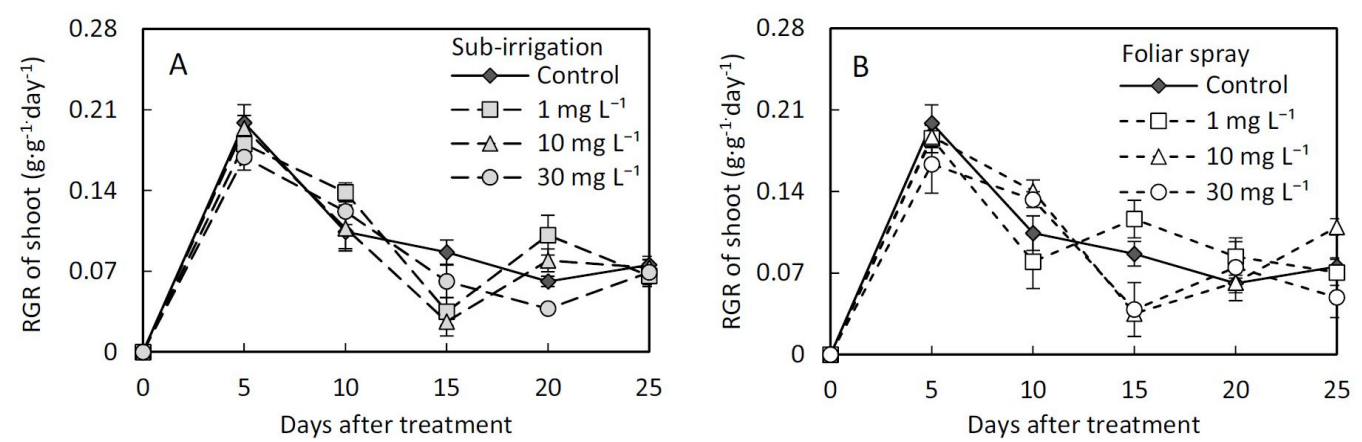

Fig. 2. Change of relative growth rate of shoot of grafted tomato seedlings subjected to sub-irrigation (A) and foliar spray (B) of diniconazole. 
Effects of Different Application Approaches with Diniconazole on the Inhibition of Stem Elongation and the Stimulation of Root $\cdots$
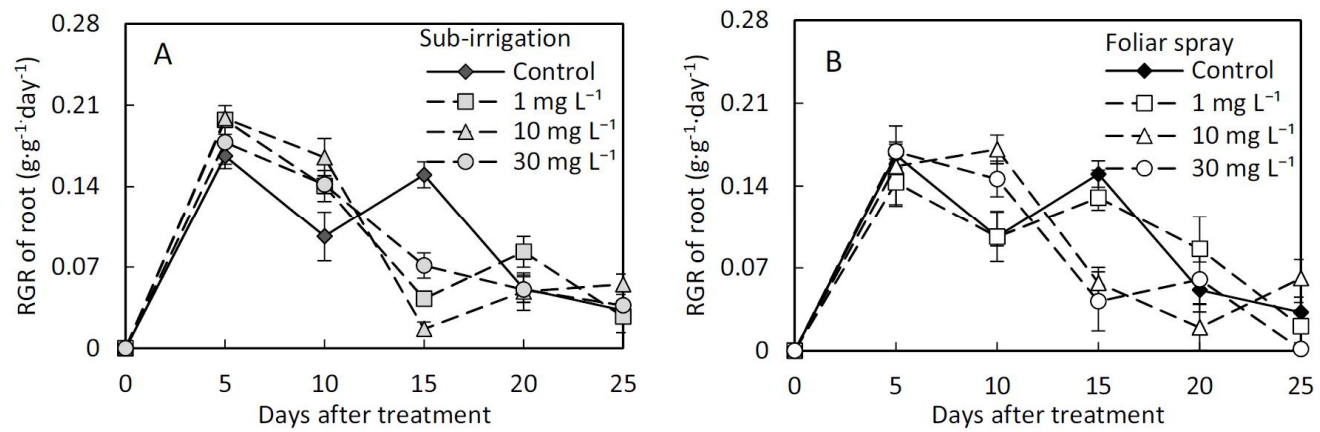

Fig. 3. Change of relative growth rate of root of grafted tomato seedlings subjected to sub-irrigation (A) and foliar spray (B) of diniconazole.
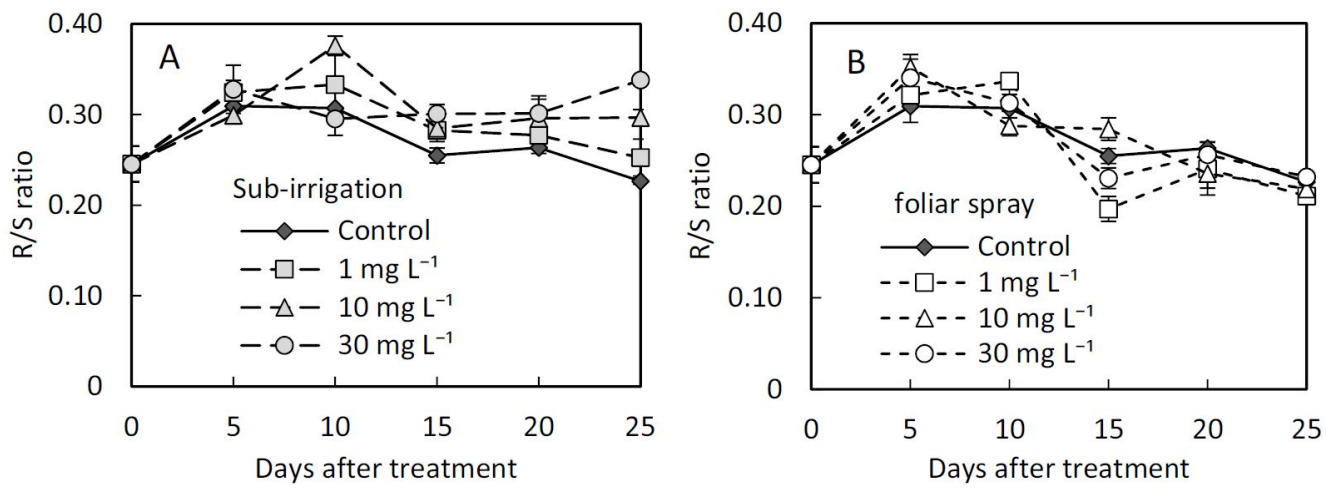

Fig. 4. Change of root to shoot ratio of grafted tomato seedlings subjected to sub-irrigation (A) and foliar spray (B) of diniconazole.
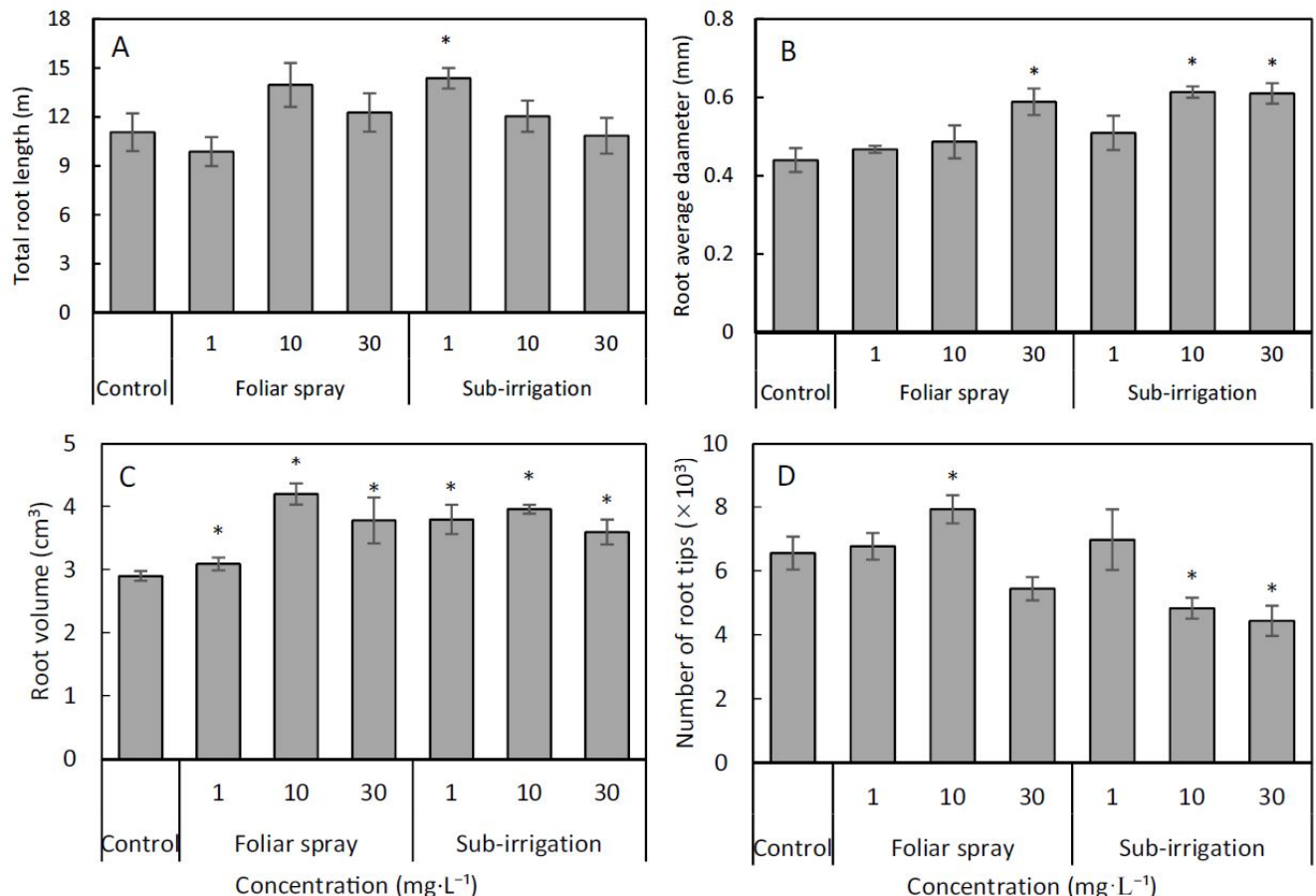

Fig. 5. Total root length (A), root average diameter (B), root volume (C), and number of root tips (D) of grafted tomato seedlings subjected to foliar spray and substrate sub-irrigation of diniconazole. The asterisk $\left(^{*}\right)$ indicates the statistical significance of $\mathrm{P} \leq 0.05$ compared with control. 
Dong Cheol Jang, Chan Xu, Si Hong Kim, Dae Hoon Kim, Jea Kyung Kim, Jea Yun Heo, Ngoc Thang Vu, Ki YoungChoi, and Il Seop Kim
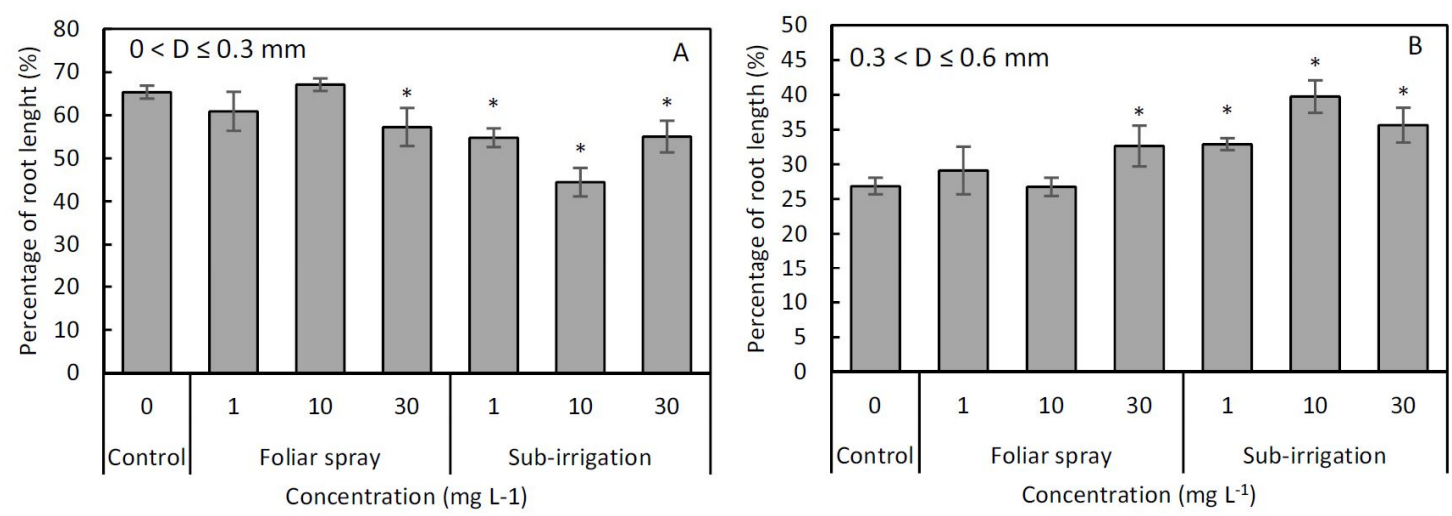

Fig. 6. Percentage of total root length with different diameters of grafted tomato seedlings subjected to foliar spray and sub-irrigation of diniconazole. Panel A shows total root length with the diameter range of 0 to $0.3 \mathrm{~mm}$ (fine root); Panel B shows total root length with the diameter range of 0.3 to $0.6 \mathrm{~mm}$. The asterisk $\left(^{*}\right)$ indicates the statistical significance of $\mathrm{P} \leq 0.05$ compared with control.

length of $29 \%$ and $8 \%$ in sub-irrigation treatment at the concentration of 1 and $10 \mathrm{mg} \cdot \mathrm{L}^{-1}$, and of $26 \%$ and $11 \%$ in spray treatment at the concentration of 10 and $30 \mathrm{mg} \cdot \mathrm{L}^{-1}$ (Fig. 5A). There were significant decreases in the total root length with the diameter range of 0 to $0.3 \mathrm{~mm}$ in all concentration of sub-irrigation treatments and $30 \mathrm{mg} \cdot \mathrm{L}^{-1}$ spray treatment, however, significant increases in total root length with the diameter range of 0.3 to $0.6 \mathrm{~mm}$ (Fig. $6 \mathrm{~A}$ and 6B). Root average diameter tended to be larger when diniconazole was applied both in spray and sub-irrigation. Mean per seedling of control was $0.44 \pm 0.03 \mathrm{~mm}$ but the value of the diniconazole treated seedlings above $0.47 \pm$ $0.01 \mathrm{~mm}$ and the largest was $0.61 \pm 0.02 \mathrm{~mm}$ in $10 \mathrm{mg} \cdot \mathrm{L}^{-1}$ subirrigation treatment (Fig. 5B). Root volume also increased sharply except $1 \mathrm{mg} \cdot \mathrm{L}^{-1}$ spray treatment. The mean per seedling of control was $2.90 \pm 0.07 \mathrm{~cm}^{3}$ and the increased root volume varied from $3.59 \pm 0.19 \mathrm{~cm}^{3}$ to $4.19 \pm 0.10 \mathrm{~cm}^{3}$ (Fig. 5C). Both foliar spray and sub-irrigation diniconazole not affected the number of root tips at $1 \mathrm{mg} \cdot \mathrm{L}^{-1}$ solution concentration but decreased that at $30 \mathrm{mg} \cdot \mathrm{L}^{-1}$ (Fig. 5D). Increase in the number of root tips was observed in $10 \mathrm{mg}$. $\mathrm{L}^{-1}$ spray treatment, conversely, significant reductions in sub-irrigation treatments (Fig. 5D).

\section{Discussion}

It has been reported that soil applications of triazole compound paclobutrazol to be more effective in controlling stem growth than foliar applications (Wieland and Wample,
1984; Kvien et al., 1987). In this study, like paclobutrazol, the application of diniconazole also showed similar results. The responses to different application approach in suppressing height growth are consistent with the mechanism that the PGR activity of diniconazole in root absorption was higher than that in shoot absorption (Kvien et al., 1987). Substrate applications of diniconazole maximized the PGR activity to enhance the retarding effect. Our results consistent with this idea, even concentration as low as $1 \mathrm{mg} \cdot \mathrm{L}^{-1}$ in substrate sub-irrigation treatment significantly reduced plant height than foliar spray. And for a similar retarding effect, the concentration of diniconazole in foliar applications was far more than substrate applications. In tomato seedling production, the appropriate inhibition rate of stem length is about $20 \%$ to $30 \%$. For reaching this target, foliar application concentration of diniconazole may have to exceed $10 \mathrm{mg}$. $\mathrm{L}^{-1}$, however, only approximately $1 \mathrm{mg} \cdot \mathrm{L}^{-1}$ was required in the substrate application (Fig. 1).

Lee and Rho described the growth suppressing effect from triazole compounds is temporary and ephemeral (Lee and Rho, 2000). The trends that increase in root and decrease in shoot were reversed at 5 and 10 days after treatment compared with control (Fig. 2 and 3). These results are consistent with the temporary and ephemeral retarding effect. This may associate with the hormones changes which also contributes to the shoot growth suppressing. Diniconazle is thought to delay the biosynthesis of gibberellin and cause the growth inhibition of plants (Kim, 2008). Besides, diniconazole is also known to inhibit endogenous ABA 
Effects of Different Application Approaches with Diniconazole on the Inhibition of Stem Elongation and the Stimulation of Root...

catabolism to break its balance thereby increasing the accumulation of ABA (Suttle et al., 2012). Those hormones changes are ephemeral, plants themselves may fastly restore the hormone balance through a variety of physiological and biochemical mechanisms. Our substrate application allowed diniconazole to remain in the substrate for longer periods than foliar spray to maintain stimulating. Furthermore, the foliage spray is easy to affect by various environmental factors such as wind and temperature, however, substrate application may overcome this drawback.

We expect to obtain a strong root system by diniconazole stimulating because triazole compounds have also been shown to influence root growth (Fletcher et al., 2000). It is important to note that the effects on root appear to inhibit or stimulate depending on the plant and the concentration (Fletcher et al., 2000). Data from previous studies have shown that the root to shoot ratio $(\mathrm{R} / \mathrm{S})$ of plants treated with triazole increased, and taking root ratio also increased after transplanting in certain plants (Jung et al., 2020; Kim and Suzuki, 1989; Zhang et al., 2003). Similarly, in this study, results showed a significant increase in total root length and root volume by substrate applications of a lower diniconazole concentration but not by foliar applications, also, R/S ratio was increased by substrate applications, but not by foliar spray. Those results suggested that it is possible to enhance the tomato root system by diniconazole stimulating. The responses in root growth are consistent with at least two mechanisms. First, the triazole compounds have an auxinlike effect (Shin and Jeong, 2002), and the auxin promotes root growth by modulating gibberellin response $(\mathrm{Fu}$ and Harberd, 2003), likewise, triazole compounds also involved in modulating gibberellin. The second possible mechanism associate with cytokine-like properties and the increasing cytokinin in roots. It has been reported that triazole compounds probably induce plants to produce more cytokinins by stimulating root growth, but rather act as a cytokinin (Fletcher and Arnold, 1986). The reduction of fine roots and the increase of thick roots may be involved in nutrient allocation (Fig. 6), and this may be one of the reasons for the increase in average diameter. Another explanation is that diniconazole may induce an increase in the number of rows and the diameter of cortical cells thus result in average diameter increasing. Notably, root penetration increases with root diameter (Clark et al., 2008). Therefore, the increase in root average diameter may be positive.

Our results suggested that the substrate application maximized the PGR activity of diniconazole to enhance the retarding effect. And, substrate application may overcome some drawbacks of foliar spray, such as the influence of wind and temperature. Further, it is possible to enhance the tomato seedling root system by diniconazole stimulating with a lower concentration.

\section{Acknowledgement}

This study was supported by the Rural Development Administration joint project (project number: PJ012827022020).

\section{Literature Cited}

Bausher, M. and G. Yelenosky. 1987. Morphological changes inCitrus associated with relatively high concentrations of paclobutrazol. Journal of Plant Growth Regulation. 5:139-147.

Cho, E.H. and M.H. Chiang. 1997. Effect of nutrient concentration and plant growth regulators on rooting in coleus stem cuttings. J. Bio. Fac. Env. 6:277-283.

Choi, S.H., J.S. Kang, Y.W. Choi, Y.J. Lee, Y.H. Park, M.R. Kim, B.G. Son, H.K. Kim, H.Y. Kim, and W. Oh. 2011. Effect of diniconazole on growth and flowering of Vinca rocea and Salvia splendis. Journal of Life Science. 21: 1004-1008.

Clark, L.J., A.H. Price, K.A. Steele, and W.R. Whalley. 2008. Evidence from near-isogenic lines that root penetration increases with root diameter and bending stiffness in rice. Functional Plant Biology. 35:1163-1171.

Fletcher, R, and V. Arnold. 1986. Stimulation of cytokinins and chlorophyll synthesis in cucumber cotyledons by triadimefon. Physiologia plantarum. 66:197-201.

Fletcher, R.A., A. Gilley, N. Sankhla, and T.D. Davis. 2000. Triazoles as plant growth regulators and stress protectants. Horticultural reviews. 24:55-138.

$\mathrm{Fu}, \mathrm{X}$. and N.P. Harberd. 2003. Auxin promotes Arabidopsis root growth by modulating gibberellin response. Nature. 421:740-743.

Jaleel, C.A., G. Lakshmanan, M. Gomathinayagam and R. Panneerselvam. 2008. Triadimefon induced salt stress tolerance in Withania somnifera and its relationship to antioxidant defense system. South African Journal of Botany. 74:126-132. 
Dong Cheol Jang, Chan Xu, Si Hong Kim, Dae Hoon Kim, Jea Kyung Kim, Jea Yun Heo, Ngoc Thang Vu, Ki YoungChoi, and Il Seop Kim

Jung, M.J., H.Y. Kim, and K.B. Lim. 2020. Effect of diniconazole on the growth and taking roots after transplanting of Sesamum indicum 'Baekseol' plug seedlings. Journal of Crop Science and Biotechnology. 1-5.

Kim, H.Y, and Y. Suzuki, Y. 1989. Changes in assimilated 13C distribution and soluble acid invertase activity of Zinnia elegans induced by uniconazol, an inhibitor of gibberellin biosynthesis. Plant physiology. 90:316-321.

Kim, H. 2008. Effect of diniconazole on growth and flowering of Gomphrena globosa and Calendula officinalis. J. Korean Soc. Plant People Environ. 11:47-51.

Kishorekumar, A. 2006. Differential effects of hexaconazole and paclobutrazol on the foliage characteristics of Chinese potato (Solenostemon rotundifolius Poir., JK Morton). Acta Biologica Szegediensis. 50:127-129.

Kvien, C., A. Csinos, L. Ross, E. Conkerton, and C. Styer. 1987. Diniconazole's effect on peanut (Arachis hypogaea L.) growth and development. Journal of Plant Growth Regulation. 6:233-244.

Lee, S. and K. Rho. 2000. Growth control in 'New Guinea' impatiens (Impatiens hawkeri hybrida) by treatments of plant growth retardants and triazole fungicides. Korean Journal of Horticultural Science \& Technology. 18:827-833.

Shin, W.G. and B.R. Jeong. 2002. Seed treatment of growth retardants for height suppression of pepper plug seedlings.

Suttle, J.C., S.R. Abrams, L. De Stefano-Beltrán, and L.L. Huckle. 2012. Chemical inhibition of potato ABA-8'hydroxylase activity alters in vitro and in vivo ABA metabolism and endogenous ABA levels but does not affect potato microtuber dormancy duration. Journal of experimental botany. 63:5717-5725.

Wieland, W. and R. Wample. 1984. Effects of paclobutrazol on shoot growth, photosynthesis, and root growth in apple. HortScience. 19:529-529.

Zhang, C.H., I.J. Chun, Y.C. Park and I.S. Kim. 2003. Effect on the inhibition of over-growth of plug seedling by triazoletype growth regulator treatment. Protected Horticulture and Plant Factory. 12:139-146.

Zhang, G., M. Johkan, M. Hohjo, S. Tsukagoshi and T. Maruo. 2017. Plant growth and photosynthesis response to low potassium conditions in three lettuce (Lactuca sativa) types. The Horticulture Journal. 86:229-237.

\title{
생장조절체 처리가 원통형 종이포트묘의 도장 억제 및 근권부 발달에 미치는 영향
}

\author{
장동철 $^{1 \dagger} \cdot{\text { 수 } \text { 찬 }^{2 \dagger} \cdot \text { 김시홍 }}^{2} \cdot$ 김대훈 $^{2} \cdot$ 김재경 $^{2} \cdot$ 허재윤 $^{3} \cdot$ 넉탕부 $^{4} \cdot$ 최기영 $^{5} \cdot$ 김일섭 $^{6 *}$
}

${ }^{1}$ 강원대학교 원예학과 박사후연구원, ${ }^{2}$ 강원대학교 원예학과 학생, ${ }^{3}$ 강릉원주대학교 식물생명과학과 교수, ${ }^{4}$ 베트남국립대학교 강사, ${ }^{5}$ 강원대학교 미래농업융합학부 교수, ${ }^{6}$ 강원대학교 원예학과 교수

\begin{abstract}
적 요. 본 연구는 원통형 종이포트 토마토 육묘시 Diniconazole의 처리방법이 도장억제 및 근권발달에 미치는 영 향을 검토하기 위하여 수행되었다. 그 결과, 엽면적, LAR, 초장, 충실도, 생체중, RGR 및 R/S 에서 시험구간 유의한 차이를 보였다. 동일한 농도를 처리했을 경우, 근권부와 지상부의 흡수도 차이로 인해 저면관수가 엽면살포에 비해 도장억제에 효과적이었다. 저면관수는 엽면시비의 10 분의 1 의 농도만으로도, $20 ~ 30 \%$ 정도의 동일한 도장억제 효 과를 얻을 수 있었다. 디니코나졸 처리에의한 근권부 반응이 흥미로웠는데, 저면관수시 총근장, 근권부피, 평균 근 경 및 근단수가 증가하였다. 특히, $0.3 \mathrm{~mm}$ 이하의 초미세근이 감소하고 $0.3 \sim 0.6 \mathrm{~mm}$ 의 세근이 증가하였다. 따라서 원 통형 종이포트 육묘시 저면관수를 하는 것이 기존 엽면시비에 비해 사용량이 적으면서도 도장억제 및 근권부 활착 률을 높힐 수 있을 것으로 판단된다.
\end{abstract}

추가 주제어: 도장, 뿌리발달, 생육조절, 트리아졸 내성, 토마토육묘 